\title{
Investment Approval Process of ISLAMIC Banking - An Identical Investment Approval Process Model: A Case Study on Some Selected Islamic Banks in Bangladesh
}

\author{
Md. Shahinoor Rahman, Md. Shafiul Islam, Md. Morshadul Hasan Arif \\ Department of Accounting and Information Systems, Begum Rokeya University, Rangpur, Bangladesh \\ Email address: \\ shahin_brur@gmail.com (Md. S. Rahman), shafiul.pbrur@gmail.com (Md. S. Islam), arif.morshad@gmail.com (Md. M. H. Arif) \\ ${ }^{*}$ Corresponding author
}

\section{To cite this article:}

Md. Shahinoor Rahman, Md. Shafiul Islam, Md. Morshadul Hasan Arif. Investment Approval Process of ISLAMIC Banking- An Identical Investment Approval Process Model: A Case Study on Some Selected Islamic Banks in Bangladesh. International Journal of Business and Economics Research. Vol. 5, No. 5, 2016, pp. 155-160. doi: 10.11648/j.ijber.20160505.14

Received: June 29, 2016; Accepted: July 22, 2016; Published: September 22, 2016

\begin{abstract}
Bangladesh is a developing country having various religious people. The majority portion of people is Muslim in this country. Bangladesh is in a growing stage of Business and its development. Banking sector is one of the best source of this development in Business. For being one of the developing country as well as Muslim country, there are several variation in this banking systems. General commercial banks and some Islamic banks are doing business today across this country but their systems of banking is different. Researchers had a curiosity of finding out those differences in this paper researchers tried to find out the dissimilarities in investment approval process of Islamic Banks with investment approval process or credit or loan approval process of others commercial banks. Researchers also tried to review the actual and identical investment process of Islamic banks as well as differences with other commercial banks. Researchers used both direct and indirect method to collect data on this rigorous issue. Researcher took several Islamic Banks and worked on their investment process. Researchers found several dissimilarities with general commercial banks' credit approval process. Finally researchers recommended a specific and complete model for investment approval process of Islamic Sariah Oriented banks.
\end{abstract}

Keywords: Investment, Investment Process, Investment Approval Process, Credit Management

\section{Introduction}

Banks are financial institutions engaged in boosting national savings and capital formation as well as constituting infrastructure through the financing of various development projects in many countries and Bangladesh is not exception here. It performs multi-dimensional activities like borrowing and lending of money, drawing, collecting and discounting bills, transferring funds, save deposit, vault/locker service, foreign exchange transactions etc. The world of banking is undergoing a transformation. Banking today has evolved into a highly competitive and sophisticated business in which technology increasingly provides the edge. Today's customers want service and information to be provided at all times and places. As Bangladesh is one of the largest Muslim countries in the world, the deep commitment of the people of this country to the Islamic way of life according to the Holy Quran and the Sunnah. Obviously, it remains a deep cry in their hearts to fashion and design their economic lives in accordance with the concept of Islam.

\section{Objectives of This Research}

Researchers desired to make the readers known about investment approval process of Islamic Banking. So the main objectives of this paper is to find out the specific investment approval process. Besides researchers also try to find out some other specific objectives. Those objectives are pointed out as follows;

- To develop an identical model for investment approval process

- To gather knowledge about the functions and transactions of investment department of bank, 
- To analysis customer satisfaction on investment of Islamic banking,

- To be acquainted with how bank perform its investment operation,

- To understand the difference between credit and investment and

- To know the difference between Islamic banking and conventional banking system.

\section{Literature Review of this Report}

Here the researcher tried to prepare a report on "Investment Approval Process of ISLAMIC Banking and an Identical Investment Process Model: A Case Study on Islamic Banking in Bangladesh". The researcher tried to prepare an identical article and the researcher tried best to prepare an identical report with authentic information. The researcher found that report on "Investment approval process of ISLAMI Banking and an Identical Investment process model" is never done by any other person. But there are lots of articles relating investment management, Investment risk management, credit risk management etc. In the literature review section-the researcher tried to show the previous finding of various articles or report related to this report.

Asian Development Bank published an article named "Loan Disbursement Handbook" in January, 2007. They included basic disbursements policy, Loan and grant regulations. They showed various disbursement guideline and practices systems dividing various section such as; general guideline, loan account, disbursement letter, actions to be taken by borrower, basic requirement for disbursement, application withdrawal systems, Eligible/Ineligible Expenditures, Capitalization of Interest, Front-end Fees, and Other Charges, Refunding process, retention money and bank guarantee process. And they also highlighted in this report the following contents, such as;

- instructions for withdrawal of loan proceeds;

- disbursement procedures;

- direct payment procedure;

- commitment procedure;

- reimbursement procedures; and

- loan information reports

The world bank published an article named 'Urban Development Series Knowledge Papers' on 'Guidebook on Capital Investment Planning for Local Governments' by 'Urban Development \& Local Government' department and specially this article prepared by 'Olga Kaganova' at 2011. Basically this article included 'Investment Planning Process' (page 29-40) and 'Implement and Monitoring Investment Project (page 40-43).

Bearing Point Inc. published an article named 'The Credit Process' that is founded by USAID at 2006. This article includes the overall credit process. This overall credit process also includes the credit process, the credit initiation and analysis process, credit underwriting, loan monitoring, credit workout and evaluation of the credit process.

CASEWARE ANALYTICS provide a solution for a case on 'Loan Portfolio Monitoring Overview'. They mention some process of loan portfolio monitoring. Basically CASEWARE ANALYTICS platform automates the definition of governance, risk and control within a financial institution's lending process. The mention commercial lending, better risk management systems, proactive management of the portfolio. They subdivide the solution into three stages; these are Organization, servicing and loan management. This solution published at 2014.

World Bank published some guideline named 'Disbursement Guidelines for Projects'. The purpose of these Guidelines is to set out the Bank's procedures for disbursement of loan proceeds for projects. Specifically, the Guidelines explain (a) the different methods used by the Bank to disburse loan proceeds, (b) the requirements for withdrawal from the Loan Account, (c) the types of supporting documentation that the borrower may be required to provide to demonstrate the use of loan proceeds for eligible expenditures, (d) the criteria for establishing designated accounts, (e) the terms and conditions applicable to advances, (f) the types of actions that the Bank may take if it determines that loan proceeds are not needed or have been used for ineligible purposes, and $(\mathrm{g})$ the consequence of refunds. This procedure published at May 1, 2006.

As a modern and competitive bank, Social Islami Bank Limited (SIBL) maintains all of the disclosure principles of accounting and publicly publishes their annual report every year. As this consequence, they published their annual report on 2014 and this report showed every types of information of the bank's literature overview. They showed their overall financial position and financial performance. They introduced their various investment products. But they never introduced their total investment process. So, when the researcher was searching for information about 'investment approval processes' then I didn't get any information that directly related with Investment approval process.

\section{Methodology of the Study}

The researcher used both physical and indirect survey in order to carry out this research. In one fruitful research both direct and indirect survey is important. As Bangladesh is a Muslim country and most people believe in Islamic Sariah, Islamic banking plays an important role in this economy. In Islamic banking 'Investment' is an important term. So, after considering this factor "investment approval process" is selected as the research issue by the researcher. After selecting the research issue, the researcher formed a questionnaire. This questionnaire included about exploration of the term investment, the process of investment, the time for the total investment approval process, the sanctioning systems, the disbursement systems, the monitoring systems etc. All of these information have collected from both the primary and secondary sources. These sources are specified below;

Primary Sources:

Primary sources are as follows: Data collected for the first 
time is called primary data. The methods used to collect such data include:

- Face-to-face conversation with the respective officers and staffs of the Branch.

- Informal conversation with the clients.

- Practical work exposures from the different desks of the departments of the Branch covered.

Secondary Sources of Data:

Researchers have collected secondary data from the following sources,

a. Annual Financial Statements of Al-Arafah Islami Bank (AIBL), Islami Bank Bangladesh Limited (IBBL), Export Import Bank of Bangladesh Limited (EXIMBBL), First Secuirity Islami Bank Limited (FSIBL), Shahjalal Islami Bank Limited (SJIBL), ICB Islami Bank Limited (ICBIBL): 2014.

b. Unpublished data from the Social Islami Bank Limited (SIBL) Rangpur Branch.

c. Manuals of Social Islami Bank Limited (SIBL), Islami Bank Bangladesh Limited (IBBL), First Secuirity Islami Bank Limited (FSIBL) and Shahjalal Islami Bank Limited (SJIBL) regarding investment business.

d. Credit Risk Manual by Bangladesh Bank.

e. Website of the Al-Arafah Islami Bank (AIBL), Islami Bank Bangladesh Limited (IBBL), Export Import Bank of Bangladesh Limited (EXIMBBL), First Secuirity Islami Bank Limited (FSIBL), Shahjalal Islami Bank Limited (SJIBL), ICB Islami Bank Limited (ICBIBL)'s

f. Annual Reports of Al-Arafah Islami Bank (AIBL), Islami Bank Bangladesh Limited (IBBL), Export Import Bank of Bangladesh Limited (EXIMBBL), First Secuirity Islami Bank Limited (FSIBL), Shahjalal Islami Bank Limited (SJIBL), ICB Islami Bank Limited (ICBIBL) 2014.

\section{Theoretical Discussion}

\section{Investment:}

An investment, synonymous with credit, is the activity that bank fixing their capital as funding or credit in order to earning an interest amount from the capital amount. The term providing credit in case of a bank is similar with the term investment. Bank invests their money in various terms such as short term investment, mid-term investment, and long term investment. Bank invest their money in various sector such as, long term property, short term property, working capital financing and various sector. Bank gives their money as a funding with a fixed interest rate. Clients must have to pay the specific interest for the funds. This interest is the main source of income of a bank.

\section{Clients:}

A person who applies for funding from bank and has an account in the bank is treated as their client. A client is the main customer of a bank. Bank always depends on their business and the more the bank has client the bigger their investment.
Deposit:

Bank provides service to the people by saving their money is called deposit. Bank collect money agreeing to give back interest amount with the principal amount is called deposit. Bank deposit rate varies with bank to bank and there are different deposit policies of every bank but most of them are almost same. Deposit is always treated as liabilities of the bank.

\section{Loan (General Banking Term):}

Actually loan, the term used in general banking which is denoted as investment in Islami banking, the act of giving money, property or other material goods to a another party in exchange for future repayment of the principal amount along with interest or other finance charges. In Islami banking term, Investment denote helping client by providing economical support with a repayment agreement including specific rate. Investment may be for a specific, one-time amount or can be available as open-ended credit up to a specified ceiling amount.

\section{Investment Report:}

An investment report is a detailed report of an individual's credit history. An investment report is used by bank to determining a find applicant's creditworthiness. This report also include the following information.

- Personal data

- Summary of credit history

- Detailed account information

- Applicant's credit history at a glance

\section{Investment Risk:}

When risk arises for default investment it is called investment risk. It is a negative phases of investment process. Sometimes investment risk arises for failure of proper use of the fund. If credit risk arise then there are always an option to recover the risk by the mortgage which given by the client at time of taking funding facility.

\section{Interest and Interest Rate:}

Interest is the amount that is paid for the use of any funding amount. Interest rate is a rate which is charged to the clients for taking the funding facilities. An interest rate is always expressing an annual percentage of the investment principal amount. It is calculated by dividing the amount of interest by the amount of principal amount. This rate can fluctuate in different situation and it's totally depends on economic condition of the national economy, inflation rate and central bank policy

\section{Investment Period:}

Funding is given for specie period. It can be short term or long term. The time limitation depends on bank. Islamic banking generally provides funding on working capital for any business. Sometimes they provide long term funding on various project. But funding on a project is very rare.

Mortgage:

Mortgage is a debt instrument, secured by the collateral of specified investment that the borrower is obliged to pay back with a predetermined set of payments. Mortgages are used by individuals and businesses to make an investment agreement. 
It is used in an investment process in order to secure the investing amount of the bank. Over a period of many years, the borrower repays the funding amount plus interest, until he/she eventually owns the property free and clear. Mortgages are also known as "liens against property" or "claims on property." If the borrower stops paying the mortgage, the bank can foreclose.

Investment Activities:

- Provide funding: First investment activities of SIBL are providing funding to their clients.

- Communicating With Clients: After providing fund, the bank personnel have to keep good communication with the clients.

- Coordination of the investment: After giving fund, bank has to coordinate the business activities of clients to check whether clients use the funds effectively or not.

- Collecting investment installment: Collecting investment installment is general but important task for investment officer or bank personnel.

- Collecting interest amount: Interest is the main source of income of a bank. So bang has to collect interest properly from the clients.

\section{Findings of this Research}

Researcher tried to find out the investment approval process of different Islamic Sariah Oriented banks and they found different banks follow different ways of investment/ credit approval process. But a few banks follows the specific and complete process. Researcher found that some banks follow only one screening stage, documentation procedure and sanctioning procedure but there's a lot of lot risk factors in approving the investment or funding proposal such as; risk is arisen for,

- Documentation inaccuracy

- Unsafe mortgage and security systems

- Wrong selection of client

- Possibility of Bankruptcy

- Wrong identity of clients etc.

To avoid this types of risk, every banks should follow a specific and complete process of screening, documentation, mortgage and sanctioning. After analyzing the findings and the risk factors researchers tried to provide a helpful and supportive investment approval process model to make the investment safe. The researcher believe that a comprehensive and well organized model can make all investment safe and profitable. The general bank can also be benefited from this model of at the time of sanctioning loan.

\section{Investment Approval Process Model}

Different Islamic Sariah oriented banks follow their own policy for investment/funding proposal. After a long data colleting period, the researcher showed a funding approval procedure that'll be helpful for both general banking and Islamic banking. The researcher guess that, his prepared disbursement systems will acceptable and he was trying to show the total stated procedure following with a shaped chart;

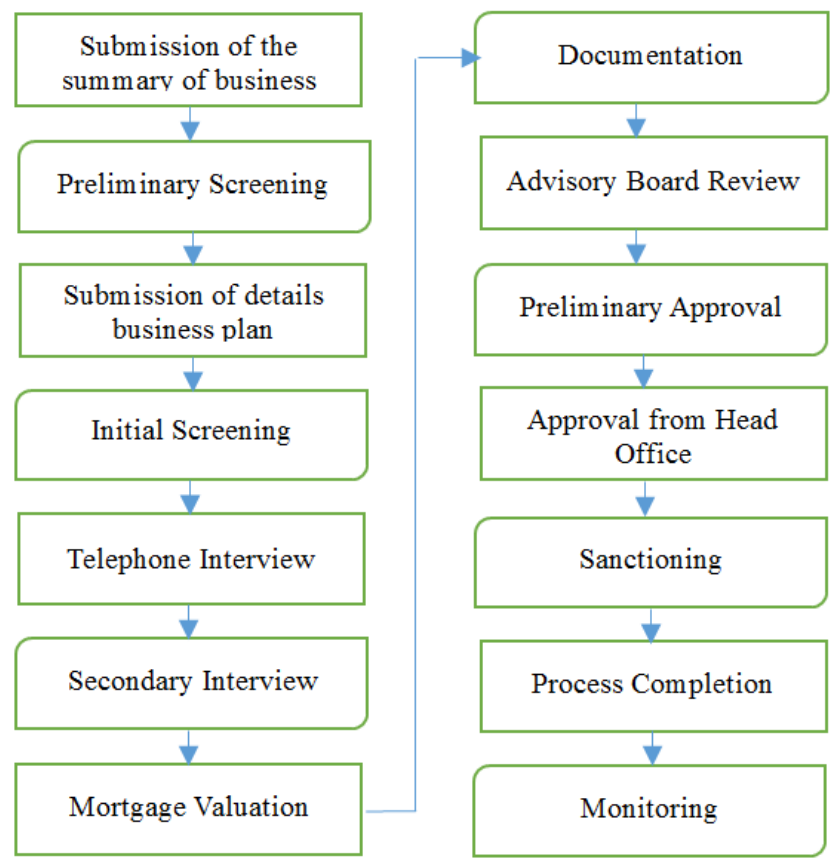

Fig. 1. Flow of Investment Approval Process.

a. Submission of the Summary of Business:

The person applying for a funding proposal has to prepare an executive business plan. It is the first step of funding proposal. Executive business plan can include
A. Background of the business;
B. Purpose of the business;
C. Product or service of the business;
D. Present financial condition and;
E. Estimated funding amount.

b. Preliminary Screening:

Preliminary screening can be a small stage of funding proposal. Bank will check the executive business plan preliminary and it will help to make a decision for next step.

c. Submission of Details Business Plan:

The person applying for a funding proposal must have to prepare his full business plan. Mission, Vision, Goal everything will included in Business plan. This Business plan will help the applicants to receive funding from the bank. So, Applicants is emphasized for preparing a rigorous business plan. A full business plan must have included the following contents;

I. Cover Page (Company Name, Logo Contact Person Address and Phone Number Date and State of Incorporation Confidentiality and Nondisclosure Statement)

II. Executive Summary

III. Body of Business Plan

- Background and Purpose

- Market Analysis

- Product or Service Development

- Marketing 
- Financial Data

- Organization Structure and Management

- Ownership

- Risk Factors

IV. Conclusion

i). Summary

ii). Timetable for funding and future development

V. Appendices

- Photograph of Product or Service

- Sales and Profitability Objectives

- Market Surveys

- Production Flowchart

- Marketing Materials

- Advertisements

- Press Releases

- Historical Financial Statements

- Table of Current Profit and Loss Statement

- Projected Profit and Loss Statement

- Cash flow Projections

- Balance Sheet

- Projected Balance Sheet

- Asset Acquisition Schedule

- Break-Even Statement

- Key Contracts

d. Initial Screening:

After preliminary screening, applicants submit his full business plan. And in this stage of initial screening, bank consider the full business plan. If they find that this funding proposal will not go beyond the Country laws, Islamic Laws (in case of Islamic Banking) and anything harmful for the society then they goes to the next step. This is called Initial Screening. When bank find everything positive, then they approve this funding proposal for the next step. If they find anything irrelevant then they closed funding proposal for consideration.

\section{e. Direct/Telephone Interview:}

After approving the initial screening, bank can goes for the direct communication with the applicants. This communication can be directly (face to face) and by telephone. This interview will helps bank personnel for screening about applicant's current business, current business location, current business condition, Inventory/stock information and etc.

\section{f. Secondary Screening:}

It is the last part of screening, bank can engage a third party for survey. There are various third parties in market. They are work for money and this is their main job to work as a third party. This third party survey can be two types;

1. Third Party for General Survey: their task is to survey about the following factors of the clients/applicants

- Business Location;

- Property location;

- Property Area;

- Property Valuation; and

- Financial Statements Analysis

2. Lawyers; Lawyers is most important factor for secondary screening. Without lawyers survey/reporting, it is so much risky for funding anywhere. Lawyers are basically important for the following legality check.

- Property (Home) Original Deed

- Property (Business) Original Deed

g. Mortgage Valuation:

Mortgage valuation is also most important factor for the funding process. Without enough mortgages, bank should not allow any kinds of funding. So, it should check carefully. There is various method of mortgage valuation. The researcher already mentioned these above. In briefly these can be;

I. Comparable methods;

II. Repayment method;

III. Investment valuation methods;

IV. Residual Methods;

V. Cost method or Base value.

h. Documentation:

Documentation included some essential documents that will relate with the investment approval process, survey valuation process, lawyers survey, mortgage processing and many others. These documents help to secure the funding approval. If there are any misinformation or deceive information given by applicants then there's a huge possibility of embezzlement of the funding approval. The below documents should be taken in the list.

- Clients Application

- Financial Statements of applicants business.

- Manager certificate

- Visit report

- Advocate Report

- Survey report

- Property valuation report

- Applicants Bank statement

i. Advisory Board Review:

If the documentation section's everything is positive then bank can send funding proposal to the investment/loan/funding advisory board for review. Advisory board reviews all the followings;

I. Preliminary screening Report;

II. Initial Screening Report;

III. Secondary Screening Report;

IV. Mortgage Valuation Report;

V. Lawyers Report and

VI. Documentations;

If advisory board denied the funding proposal then

I. Application Closed For Consideration

II. Condition Specified for reapplication

j. Preliminary Approval:

Advisory board will generally give two types of decision; Approve or denied. If advisory board approves the funding proposal then it's turn for Branch approval. When branch gets positive sign from advisory board then branch can preliminary approve the funding proposal; it is the preliminary approval of the funding proposals. 


\section{k. Head Office Sanction:}

After preliminary approval of the branch, the investment/credit risk management team review all the documents and report. After calculating and finding out the financial condition, Investment/funding/credit team will sends the proposal to investment/credit officer for approval and disbursement. Then in the last stage investment officer, manager in charge and manager will signed for final approval and sanction.

1. Disbursement:

After approving and sanctioning from head office, Branch gets the disbursements permission. It is the last stage of funding approval process. So, in this stage, branch should confirm the applicants about the funding confirmation.

m. Process Completion and Monitoring:

Once funding proposals are disbursed, the monitoring process begins. The purpose of investment monitoring is to identify as soon as possible any changes in the borrower's financial condition or performance that impact, or may impact, the borrower's capacity to repay the outstanding loan (s) to the bank as agreed. As noted above, the primary monitoring tool is the loan agreement.

\section{Recommendation and Conclusion}

As the term 'credit' in general commercial banking and 'investment' in Islamic banking is same, the procedure of these two term also almost same. But different banks follow different formalities and different procedure in their investment/credit approval process. In this research, the full and a model procedure for investment approval process are shown. If any banks follows these stated procedure then their investment/credit management will be sound in case of risk against their funds. As Bangladesh is a Muslim country so people have special soft corner in Sariah oriented commercial activities and banking activities. Most of the people prefer these Sariah oriented banking.

\section{References}

[1] The International Bank for Reconstruction and Development. "World Bank Disbursement Guideline for Project": Loan Department-2006

[2] Case Ware IIDEA Inc. (2014). Case Ware Analytics, "Case Ware Loan Portfolio Analytics"

[3] USAID-Funded Economic Governance II Project. "Credit Risk Workshop - Intermediate": March 2006

[4] Olga Kaganova. "Guidebook on Capital Investment Planning for Local Governments" Urban Development Series Knowledge Paper-The World Bank: (October 2011)

[5] Asian Development Bank. "Loan Disbursement HandbookJanuary 2007"

[6] Bangladesh Bank. "Prudential Regulation for Banks: Selected Issue"-Updated till June 2009

[7] Jerry J. Weygandt, Paul D. Kimmel and Donald E. Kieso. Accounting Principles: $9^{\text {th }}$ Edition-2011

[8] Donald E. Kieso, Jerry J. Weygandt and Terry D. Warfield, Intermediate Accounting: $12^{\text {th }}$ edition-2013

[9] Oesterreichische Nationalbank and Austrian Financial Market Authority. Guideline for Credit Risk Management

[10] Nancy Hasey-Ross. Re-engineering the Credit Approval Process: (October 5, 2011)

[11] Hagos Mirach. CREDIT MANAGEMENT; A Case Study of Wegagen Bank Share Company in Tigray Region. Reg. No-CBE/PRO-021/01 (June 2010) 